Article

\title{
Corporate Payments for Ecosystem Services in Theory and Practice: Links to Economics, Business, and Sustainability
}

\author{
Benjamin S. Thompson
}

Citation: Thompson, B.S. Corporate Payments for Ecosystem Services in Theory and Practice: Links to

Economics, Business, and Sustainability. Sustainability 2021, 13, 8307. https://doi.org/10.3390/ su13158307

Academic Editor: Shingo Shibata and Takuya Takahashi

Received: 11 July 2021

Accepted: 23 July 2021

Published: 26 July 2021

Publisher's Note: MDPI stays neutral with regard to jurisdictional claims in published maps and institutional affiliations.

Copyright: (C) 2021 by the author. Licensee MDPI, Basel, Switzerland. This article is an open access article distributed under the terms and conditions of the Creative Commons Attribution (CC BY) license (https:/ / creativecommons.org/licenses/by/ $4.0 /)$.
Faculty of Arts, School of Social Sciences, Monash University, Melbourne 3800, Australia; benjamin.thompson@monash.edu

\begin{abstract}
Few Payments for Ecosystem Services (PES) schemes are financed voluntarily by corporations. This is perhaps unsurprising, given that limited literature on the theory and practice of PES has a dedicated focus on businesses. This article unifies the PES and business literatures in order to address the awareness and management challenges that corporations face in engaging in PES. First, it shows how corporations fit into the economic theory that underpins PES, demonstrating that corporate-financed PES schemes can exhibit a diversity and hybridity of Coasean and Pigouvian characteristics. Second, it shows how PES fits into corporate sustainability theory, demonstrating how PES can help companies achieve synergies across the economic, environmental, and social tenets of the triple bottom line; for example, by helping gain social license to operate from adjacent communities, or by using PES to meet sustainability reporting requirements related to emissions and water management. Third, it shows the different PES options available to firms based on their industrial sector, operating practices, and business strategies. The options with higher potential are maintenance and enhancement of production inputs across the supply chain, and carbon offsetting and insetting to help meet climate change mitigation regulations and avoid fines. Fourth, it identifies lessons learned when transitioning from theory to practice by synthesising the latest empirical research on corporate-financed PES schemes—considering exactly what these 'should' or 'could' resemble, for example, in terms of their additionality, conditionality, permanence, co-benefits, budgeting, and bargaining. Examples are drawn from corporate-financed schemes in forests and watersheds across Africa, Asia, Europe, Latin America, and North America. The article concludes that these schemes remain small in number and size, but have significant potential to increase-and this can be aided by future research on corporate motives, understandings, and actions on PES.
\end{abstract}

Keywords: nature-based solutions; biodiversity; conservation; environmental management; environmental finance; natural capital; environmental sustainability; corporate environmentalism; user-financing; environmental services

\section{Introduction}

Greater business support for the natural environment is urgently required [1,2]. In particular, there is a need for corporations to move beyond energy efficiency and recycling efforts performed internally [3] to supporting ex situ environmental management activities [4,5]. These have often been limited to one-off and philanthropic activities that typically seek to engender positive media attention, reputation enhancement, and brand value [2,6], such as tree planting events [7]. Now, there are calls for corporations to increase their awareness and management of the ecosystem services upon which some of their core business operations may rely [8-10]. The primary tool for this is Payments for Ecosystem Services (PES), which are defined as voluntary transactions between ecosystem service 'users' and 'providers' that are conditional on new and improved rules of natural resource management [11]. In this sense, a corporation would pay offsite landowners to change their land management practices in ways that deliver the ecosystem service(s) that it desires. PES schemes can be implemented in settings ranging from rural [12] to urban [13], and 
terrestrial [14] to marine [15], making them broadly applicable to corporations operating in a range of sectors and locations. However, greater unification is required between the PES, corporate sustainability, and business strategy literatures in order to address the awareness and management challenges that corporations face in engaging in PES [16-18].

While several articles discuss the theory and practice of PES schemes [19-23], few focus specifically on those financed voluntarily by corporations. This is an important gap in the literature because corporations are considered to be ideal and obvious PES users [24-26], and although some corporate participation is mandated by national laws in countries such as Costa Rica and Vietnam, it is voluntary engagement that is considered key to the longterm performance and scaling of PES as an environmental financing tool [27]. Nevertheless, meta-analyses have found that only $7 \%$ [28], 18\% [29], or 21\% [30] of PES schemes are corporate-financed. Furthermore, in some of these cases, the corporation may be mandated to participate through taxes or tariffs, making the percentage of voluntary participation even lower. The precise fit of corporate-financed schemes within the economic theory of PES is further compounded when corporate payments are used alongside those from NGOs, donors, and state governments [31,32]. Indeed, there is a need to clarify how corporate financing fits into the economic theory that underpins PES (addressed in Section 2).

It has been suggested that PES can help firms achieve corporate sustainability [24], but the literature contains limited theoretical insight and practical guidance on how this can be realised. In theory, corporations should view PES as a sustainable production strategy, whereby their business operations rely on ecosystem services as production inputs [4]. Alternatively, PES can help corporations mitigate reputational risks, since ecosystem services can help offset environmental damage; for example, by purchasing forest carbon credits to offset $\mathrm{CO}_{2}$ emissions [33,34]. Both of these situations can deliver environmental and direct economic outcomes for the company. However, it is emerging that some firms misconstrue PES as a philanthropic gesture or a means of gaining a social license to operate from landowners located proximal to their operation sites [4]. While this goes against PES theory (since PES is about payments being made as part of a transaction in which corporations receive important ecosystem services in return) it may be the only way that some PES schemes can get off the ground-assuming the company is content with social outcomes and indirect economic outcomes through increased reputation and sales [18]. Hence, it is necessary to unravel this nuance by considering how PES integrates with the economic, environmental, and social tenets of corporate sustainability theory (addressed in Section 3). Furthermore, since corporate involvement in PES is often driven by perceived business relevance and potential benefits [1], the various options for corporations to integrate PES into their operations should be outlined for different business needs and profiles (addressed in Section 4).

Although the subject remains under-researched, the last few years have seen a flurry of empirical studies on corporate-financed PES schemes from around the world. While many of these gauge levels of corporate and stakeholder interest in hypothetical schemes $[16,35,36]$, others have been conducted on operational schemes $[4,37,38]$. For example, it has been discovered that corporations may be restricted in their ability to participate in PES by unconducive firm-level institution such as protocols, norms, and standard operating procedures that restrict where and for how long PES activities can occur [18]. The time is ripe to synthesise these empirical findings to understand exactly what corporate-financed PES schemes 'should' or 'could' resemble, as theory is increasing developed and translated into practice (addressed in Section 5).

Accordingly, this article aims to investigate how corporate-financed PES intersects with economic theory, corporate sustainability, and business strategy. The objectives are to (1) ascertain how corporations fit into the economic theory that underpins PES; (2) demonstrate how PES fits into corporate sustainability theory; (3) elucidate the different options for integrating PES based on different business profiles and strategies; and (4) identify lessons learned for moving from theory to practice, by synthesising empirical research on corporate-financed PES. In addressing these objectives, the manuscript makes several 
novel contributions and fills the critical knowledge gaps articulated above. Throughout, the focus is on improving the integration of relevant PES and business literatures, theories, and practices. From here the manuscript is split into four distinct but related sections that together provide a current and comprehensive account of the theory and practice of corporate-financed PES. Academically, the findings are relevant to PES scholars and business scholars, while practically they are valuable for corporations interested in participating in PES and proponents seeking to develop corporate-financed PES schemes.

\section{How Corporate Financing Fits into the Economic Theory of PES}

This section identifies how and where corporations fit within the economic theory on PES, and examines their specific role under certain institutional circumstances. PES schemes are not easy to classify [39] and only a few attempts have been made to categorise their characteristics $[22,25,26,40]$.

It is widely held that PES schemes fit somewhere along a continuum between 'Coasean' and 'Pigouvian' economic theories [41]. PES was originally inspired by Coasean economics [42], which theorises that environmental externalities can be optimally managed without state government, through direct negotiation and voluntary transactions between beneficiaries (those that benefit from ecosystem services) and providers (those that supply them), provided that transaction costs are low and land tenure is clear [25,41]. A voluntary act is performed at one's free will, while negotiation requires the necessary power and intellect to bargain over the particulars of, for example, a contract. It has long been recognised that contracts and markets are equally capable of internalizing externalities [43] - and Coasean PES most commonly involves the former [11]. Ultimately, PES schemes are Coasean if they adhere to all of these three key features [11,41,44,45]:

- Participation of beneficiaries and providers is voluntary

- The payment amount is privately negotiated/bargained

- The beneficiary is also the final user of the ecosystem service(s)

It should be noted that: (1) trade does not have to take place through a financial market, meaning the payment amount is not set and can therefore be bargained. Nevertheless, trade through a market can still be considered Coasean if it is bilateral and both the beneficiary and the provider voluntarily agree to the market price; (2) trade does not necessarily have to be direct, and could pass through an intermediary, but the payment must be made by the final ecosystem service user; (3) the beneficiary does not have to come from the private sector, although this seems the most likely scenario for Coasean PES; (4) the state is seldom excluded from Coasean PES schemes altogether, and often has to be involved (even if minimally) [23,39].

Despite its Coasean inspiration, in reality the largest PES schemes conform to Pigouvian economics [46], which theorises that environmental externalities predominantly generate social costs that should be dealt with by governments [39,47]. This is typically achieved by states either mandating certain actors to participate in PES schemes, or by financing the schemes themselves. As such, PES schemes can be considered Pigouvian if they adhere to either of these features $[41,44,45,48]$ :

- State government mandates participation through the creation of a new law or policy. Note that the payment could come from the private sector, but these corporations would have been mandated to participate.

- State government is the buyer acting on behalf of broader society (which would be the final beneficiary).

Pigouvian PES tends to result in nationally-orchestrated schemes that involve many providers and beneficiaries over large geographical areas. Consequentially, it has been estimated that $>90-99 \%$ of all PES payments come from state governments [49], predominantly in China, Costa Rica, Ecuador, Mexico, and Vietnam. This dominance of Pigouvian-inspired PES schemes suggests that government intervention was necessary to bring PES to fruition-for example, through radical institutional change in the form of a 
new law, decree, or policy [50]. Paradoxically, however, many governments in developing nations may be unable to implement PES mandates or finance PES as a third party [51]. This means that the implementation of Coasean-inspired PES schemes-i.e., those that are voluntary for all participants, and likely financed by the private sector-may be crucial if PES is to scale as an environmental management approach in many nations.

Despite the binary categorisation, it is noted that there may be Coasean PES schemes in countries with Pigouvian PES laws; for instance, in cases where companies that are not mandated to comply still wish to voluntarily participate in their own PES schemes that may be independent of a national PES law. For example, Ecuador has several corporate-financed urban water projects that fit with a Coasean framework, in addition to its Pigouvian 'SocioPáramo' program [52,53], while Costa Rica has several local Coasean PES schemes in addition to its flagship 'Pago de servicios ambientales' (PSA) Program [54]. Furthermore, there are numerous cases of hybrid schemes (that are not fully Coasean and/or not fully Pigouvian), which can also occur in practice [32], for example:

- Governments may act to strongly encourage voluntary participation in PES rather than directly mandating it, potentially swaying participants and thereby reducing their free will $[45,55]$.

- Unequal power relations may mean that a buyer offers a 'take-it-or-leave-it' deal to the seller $[11,56]$. The seller still has the voluntary option of accepting or declining the offer, but if they do accept it, since no bargaining has taken place, they may not be fully satisfied with the price received [56].

Sattler and Matzdorf [41] depict this diversity using a continuum, implying that any scheme will sit somewhere between the two extremes of Coasean and Pigouvian. However, just because a scheme is 'less Coasean' does not automatically mean it is 'more Pigouvian', and vice versa. For example, Wynne-Jones [57] shows that the Glastir PES scheme in Wales is 'Coasean-like' because participation is voluntary on the part of the provider, but also 'nonCoasean' (but not necessarily any more Pigouvian) because the payment amount cannot be negotiated but rather is set by the Welsh Government based on estimated opportunity costs associated with agriculture ( $\left.£ 35 \mathrm{ha}^{-1} \mathrm{yr}^{-1}\right)$; and additionally, 'Pigouvian-like' because payment only comes from the Welsh Government (rather than a private beneficiary). This highlights the flaws of the continuum depiction, which presents an opportunity to offer a new depiction of the diversity of PES schemes. A new framing is developed here, using two axes to create four quadrants (Figure 1). The $x$-axis relates to levels of voluntariness and bargaining that the schemes exhibit (with evidence of bargaining assuming high voluntariness). The $y$-axis relates to the mode of financing, roughly divided between state financing and user financing. Several schemes were subjectively appraised for illustrative purposes, with details on the appraisal criteria given below:

$X$-axis: Levels of voluntariness and bargaining (for beneficiaries)

Beneficiaries are mandated to pay to a fund, with one main type of payer $(-3)$

Beneficiaries voluntarily pay through a fund, with multiple types of payers $(-2)$

Beneficiaries voluntarily pay through a fund, with one main type of payer $(-1)$

Beneficiaries voluntarily pay through bilateral agreement with no bargaining $(+1)$

Beneficiaries voluntarily pay through bilateral agreement with low bargaining $(+2)$

Beneficiaries voluntarily pay through bilateral agreement with high bargaining $(+3)$

Y-axis: Type of financing mode

State-financed via a subsidy $(-3)$

State-financed via a bond $(-2)$

State-financed akin to philanthropy $(-1)$

User-financed akin to tax $(+1)$

User financed for philanthropy $(+2)$

User-financed for financial gain (+3)

The novelty of this categorisation is that is it broadens out the key criteria used to coarsely differentiate between Coasean and Pigouvian PES to visualise the true diversity 
and hybridity of PES that is present in reality, and that is misrepresented by a continuum, especially in the case of corporate-financed schemes.

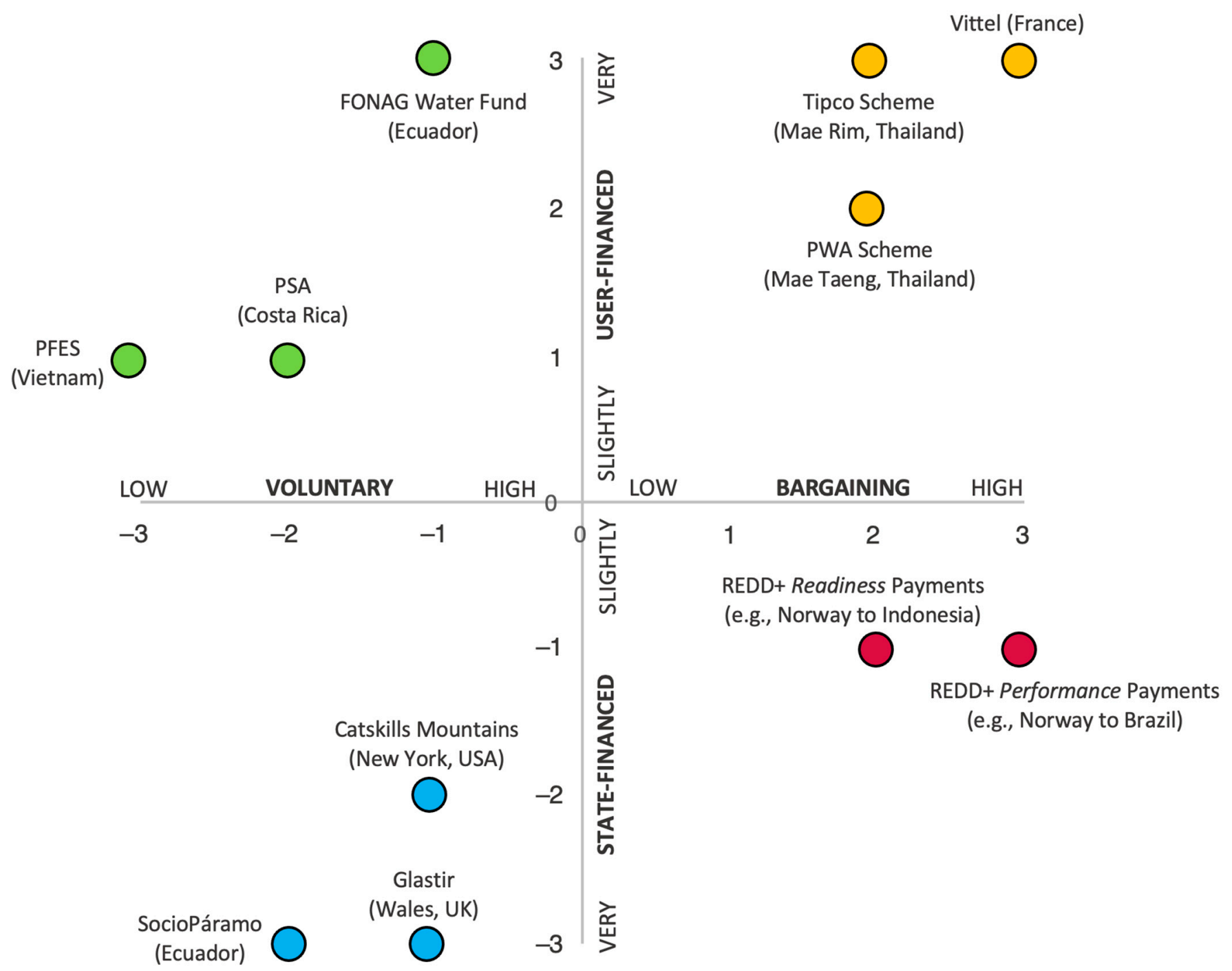

Figure 1. A representative array of PES schemes subjectively appraised based on their levels of voluntariness and bargaining $(x$-axis), and mode of financing ( $y$-axis). See main text for appraisal criteria and explanations.

Regarding the upper-left quadrant, Fondo para la proteccion del Agua (FONAG) is a PES scheme whereby corporations requiring a well-regulated and purified water supply pay upstream land managers for forest restoration and conservation. Corporations that have volunteered to pay include Quito's Public Electric Utility Company, the brewing company Cerveceria Nacional, and companies operating the Salve Faccha dam and Mica Hydroelectric dam [53]. Crucially, there are no bilateral agreements between these corporations and specific ecosystem providers; rather, the payments from the corporations go into a trust fund managed by an extra-governmental intermediary organization headquartered in Quito [53]. The Payments for Forest Ecosystem Services (PFES) scheme in Vietnam runs in conjunction with Decree 99, which mandates (primarily) hydropower companies to pay into a state-managed fund for forest restoration in the upper watersheds $[58,59]$. Costa Rica's Pagos por Servicios Ambientales (PSA) scheme is partly financed by the state through a consumer tax (making it partly Pigouvian in nature) [45], but also involves voluntary payments made by 41 private firms (making it partly Coasean in nature) [60]. These firms include hydroelectric plants, construction companies, and a brewery, and again, there are 
no direct bilateral agreements, with payments managed by an intermediary abbreviated to FONAFIFO. Payment amounts are not set and FONAFIFO contributes the difference between the payment amounts made by corporations, and the (variable) amounts that are received by different land managers [60].

In the upper-right quadrant, examples are provided from recent corporate-financed PES schemes in Thailand involving the bottled spring water company, Tipco ${ }^{\mathrm{TM}}$, and the Provincial Waterworks Authority (PWA), both located in sub-districts of Chiang Mai Province [4]. The primary difference is that Tipco aspire to improve sustainable production (in the form of maintained spring water quality and quantity) leading to greater negotiation with communities over the payment amount they are willing to accept, whilst PWA are using PES in a more philanthropic manner based on the company's willingness to pay (see Sections 4 and 5). Also included is the Vittel ${ }^{\mathrm{TM}}$ PES scheme in France, in which this famous mineral water company pays upland farmers around $€ 200 \mathrm{ha}^{-1} \mathrm{yr}^{-1}$ to avoid using agrochemicals that could jeopardise water purity [61]. While long heralded as a 'perfect' example of Coasean PES, this view has been challenged by Bingham [56] who claims the bargaining process (when negotiating the payment amount-and by extension, securing farmer participation) represents a 'substantial departure from the Coase theorem'. It is claimed that the corporation used its power as the largest landowner in the catchment and largest employer in the region to influence farmers into agreeing to lower payments than they may have been able to demand [56]. Nevertheless, negotiations did take place, and the payments do cover farmers' opportunity costs $[56,61]$, hence the position of this circle on Figure 1.

Regarding the lower-left quadrant, Ecuador's SocioPáramo is overseen by the Ecuadorian Ministry of the Environment and designed to conserve forests and grasslands [62]. It is financed by the state and international donors, with land managers receiving what are essentially subsidies ranging from USD \$30-60 ha ${ }^{-1} \mathrm{yr}^{-1}$ depending on the amount of land that a land manager decides to contribute [62]. Similarly, the Glastir scheme is described above and is entirely financed by the Welsh government as a subsidy to farmers [57]. The Catskills Mountains are a major water catchment area that supplies New York City; upriver land managers can be paid to remove sensitive streamside lands from agricultural production via the proceeds of a bond issued by the City Government [32].

Finally, the lower-right quadrant primarily regards bilateral 'Reducing Emissions from Deforestation and Degradation' (REDD+) payments between countries. Because REDD+ is a philanthropic gesture from developed countries to developing countries, the main distinguishing factor here is whether the payments are made for the completion of REDD+ 'readiness' activities such as trainings on remote sensing and protected area management (output-based conditionality), or whether the payments are made once actual reduced deforestation has been verified (performance-based conditionality) [32]. See Section 5 for clarifications on these different types of conditionality.

\section{PES and the Triple-Bottom Line}

Having identified how corporations fit within the economic theory on PES, the next step is to identify how PES fits within the theory of corporate sustainability. Corporations are increasingly concerned with corporate sustainability, which involves embedding sustainable development principles within business strategies and operations [63]. At its core are the inter-relationships between environmental, social, and economic performancesomething termed the triple bottom line (TBL) [64]. However, greater corporate action on achieving corporate sustainability is required [65], with many firms facing difficulties in aligning the TBL with their strategic management and implementing it in practice [66]. Ideally, corporate sustainability strategies and approaches can achieve synergies across the three interdependent dimensions of the TBL in tandem [67]. Oftentimes this may be achieved through looking beyond internal production processes and operations (which may already be optimised to a large extent) towards supply chains and the stakeholders within them [68]. This includes the green supply chain management of natural capital and 
ecosystem services [69]. Such corporate sustainability strategies and approaches may facilitate the measurement, quantification, and control of environmental, social, and economic value generation within the corporation and beyond [70]. PES is such an approach, able to contribute jointly to pursuing economic, environmental, and social corporate sustainability objectives. This section demonstrates how the theory and practice of PES aligns with the TBL, showing how PES can generate environmental, social, and economic benefits from the same integrated approach to sustainable production and supply chain management (Figure 2).

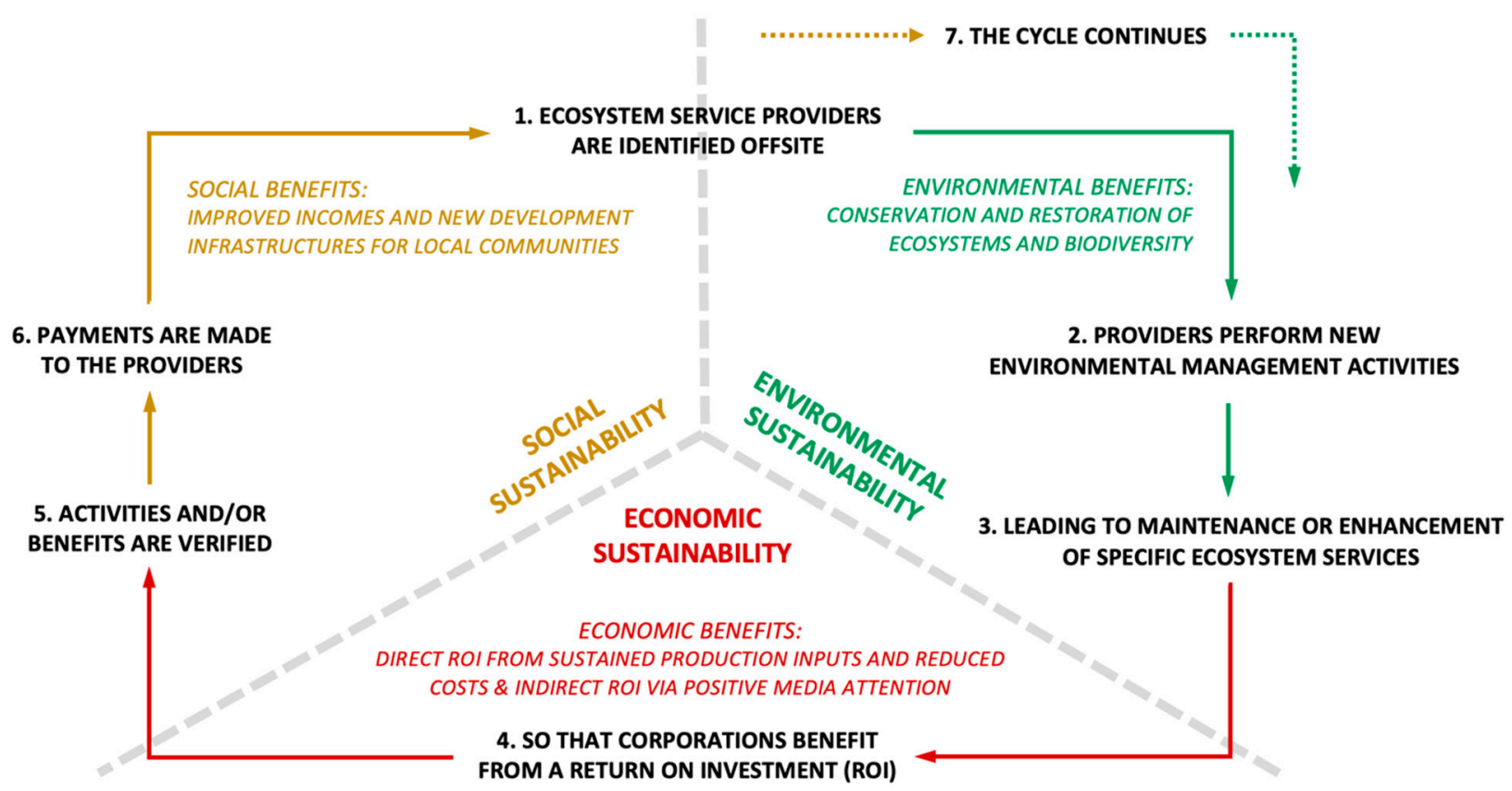

Figure 2. The main process involved in PES schemes (numbered 1-7) overlaid with the social (yellow), environmental (green), and economic (red) dimensions of the triple-bottom line.

Economic corporate sustainability involves reducing input costs per unit of output and managing operational risk [63]. In the context of PES this means maintaining the quality and quantity of production inputs across the supply chain to ensure productivity is not disrupted. Broadly, current levels of global production and consumption are using $50 \%$ more ecosystem goods and services than nature can regenerate [71]. Additionally, few firms are measuring their full environmental externalities, partly due to methodological challenges [71], although some work has sought to remedy this [72]. As a comprehensive and long-term conservation approach, PES schemes can encourage companies to measure and safeguard production inputs that are provided by ecosystem service providers from lands located off-site [73]. These services might include fresh water from upstream catchment areas, or commercially viable fish that migrate to the open ocean after being raised in threatened coastal habitats such as mangrove forests. Thus, for water utilities or fishing companies, the management of catchments and coastal ecosystems, respectively, is of great economic importance. Ultimately, corporations should expect to see prolonged or more efficient production performance, which should lead to a subsequent financial return on the payments they make to ecosystem services providers.

Environmental corporate sustainability focuses on living and nonliving natural systems, including ecosystems, land, air and water [74]. Environmental strategies such as gaining product certification (e.g., ecolabels) and becoming carbon neutral have become mainstream, since they are increasingly expected by society $[75,76]$. The latter are often achieved through corporate tree planting events and programs [7]. Despite this, commentators argue that corporations should increase their awareness of and attention towards 
their long-term ecosystem service dependencies and the major effects that biodiversity loss could have on their financial performance $[34,77,78]$. The non-linearity and irreversibility of natural capital depletion creates absolute ecological thresholds that, once exceeded (through degradation and unsustainable use), may result in ecosystem service provision cessation that will be catastrophic for business [79]. PES can help corporates achieve environmental outcomes related to biodiversity, carbon, water, and scenic beauty $[32,80]$. Indeed, if designed and implemented effectively, PES has been proven to improve ecological conditions [81,82], and reduce rates of ecosystem conversion [14,83].

Social corporate sustainability involves the wellbeing of different stakeholders such as employees, consumers, and communities [63], with the latter being most relevant in the case of PES. A socially sustainable company adds value to the communities within which it operates [74]. This is often practiced through the financing and implementation of development projects related to the education, health, or livelihoods of communities located adjacent to a firm's operation site. Philanthropic donations, which could be financial (e.g., sponsorship) or in-kind (e.g., donating products), may also be made. These are also often done for purposes of reputation enhancement and gaining a social license to operate (LTO) in certain locations [84]. Although PES primarily aims to achieve environmental benefits, it can also help corporates achieve social outcomes. Some PES schemes have reduced poverty [82] and resolved conflicts over property rights [85]. In a study of 60 PES schemes in Latin America, Bauchet et al. [80] found that 65\% support the well-being of local communities, including improving their financial situation. Cash payments made to households, for example, have been found to directly enhance income stability and diversification among households [62]. Payments accruing to ecosystem service providers can also be spent on local development and infrastructure projects such as community buildings, and are therefore potentially able to engender indirect benefits such as positive media attention. Nevertheless, it is important that firms are vigilant to the possibility that the payments are spent on activities that may create environmental harm (e.g., purchasing new fishing gear or expanding agricultural land), which could counteract the net environmental benefits of the PES scheme [86] and possibly lead to negative media coverage.

Amid research calling for greater examination of how supply-chain related sustainable practices can contribute to a corporation's TBL [87] — particularly around the potentially conflicting relationships between the economic, environmental, and social dimensions of corporate sustainability [6] — PES can present an innovative and synergistic corporate sustainability strategy on which to focus both future strategic management efforts and research attention.

Finally, a key feature of corporate sustainability and the TBL is sustainability reporting. Thus, it is worth noting that the major corporate sustainability reporting measures, Dow Jones Sustainability Indices (DJSI) and the Global Reporting Initiative (GRI), vary with their relevance to PES. Montiel and Delgado-Ceballos [88] claim that the environmental dimensions of the GRI seem more exhaustive than those of the DJSI, and this appears to be particularly true in the specific case of PES. DJSI stipulate 'climate strategy' and 'biodiversity' in their criteria, while GRI specifies 'water', 'emissions [e.g., carbon]', 'products and services', and 'biodiversity'. These criteria (particularly those of GRI) directly relate to the major types of PES schemes, i.e., watershed, forest carbon, and provisioning ecosystem services that can include raw materials such as timber. The inclusion of biodiversity in both is also crucial, since it is biodiversity that produces the ecological functions that combine to produce ecosystem services for humankind. Thus, corporations may be able to leverage their pre-existing use of sustainability reporting measures to justify their participation in PES with the board.

\section{PES Options for Different Business Profiles}

Having identified how PES can help achieve synergies across all three dimensions of the TBL, the next step is to identify the types of PES schemes that corporations may wish to participate in. The contribution PES could make to a corporate sustainability strategy will 
vary according to a business' profile (i.e., its sector and operating practices) and strategic rationale for paying for ecosystem services [77] (Table 1). Across the board, some types of PES are of higher potential to corporations than others.

Table 1. Six PES options with associated business profiles and rationales for investment.

\begin{tabular}{|c|c|c|c|}
\hline PES Options & Business Profile & Reason to Invest in ES & Example \\
\hline $\begin{array}{l}\text { 1. Maintaining ES } \\
\text { provision }\end{array}$ & $\begin{array}{l}\text { Businesses that benefit from service } \\
\text { provision, without disrupting } \\
\text { its provision. } \\
\text { (High PES potential) }\end{array}$ & $\begin{array}{l}\text { Business is using ES for free and } \\
\text { should ensure its maintenance } \\
\text { through careful environmental } \\
\text { management in areas that are essential } \\
\text { for ES provision. Direct ROI. }\end{array}$ & $\begin{array}{l}\text { Water bottling plants pay upstream } \\
\text { landowners to perform environmental } \\
\text { activities that increase water retention } \\
\text { and flows towards their } \\
\text { operation sites. }\end{array}$ \\
\hline $\begin{array}{l}\text { 2. Increasing ES } \\
\text { provision ex situ or } \\
\text { reducing ES loss } \\
\text { ex situ }\end{array}$ & $\begin{array}{l}\text { Businesses that would see improved } \\
\text { performance if there was a relative } \\
\text { increase in service provision. } \\
\text { (High PES potential) }\end{array}$ & $\begin{array}{l}\text { Business could be financially } \\
\text { motivated to invest in improving } \\
\text { services that function as production } \\
\text { inputs, thus increasing production } \\
\text { output. Direct ROI. }\end{array}$ & $\begin{array}{l}\text { Fishing companies pay coastal land } \\
\text { managers to increase mangrove } \\
\text { forests along the coastline. This can } \\
\text { improve fish catches, as mangroves } \\
\text { provide key habitat to juvenile fish } \\
\text { before they migrate to the open ocean. }\end{array}$ \\
\hline $\begin{array}{l}\text { 3. Offsetting ES loss } \\
\text { ex situ }\end{array}$ & $\begin{array}{l}\text { Businesses that neither benefit from, } \\
\text { nor disrupt service provision, but } \\
\text { whose activities do counteract the } \\
\text { benefits of service provision elsewhere. } \\
\text { (Moderate PES potential) }\end{array}$ & $\begin{array}{l}\text { Business could be legally required or } \\
\text { morally motivated to invest in } \\
\text { offsetting (increasing ES elsewhere to } \\
\text { eliminate any net loss of ES benefits). } \\
\text { Businesses 'use' the traded ES to } \\
\text { internalise negative environmental } \\
\text { externalities and avoid fines. } \\
\text { Direct ROI. }\end{array}$ & $\begin{array}{l}\text { Carbon emitters pay landowners } \\
\text { (preferably from a specific location of } \\
\text { relevance to the business) to reduce } \\
\text { deforestation or degradation, or } \\
\text { restore forest area, generating carbon } \\
\text { credits that can be used for offsetting. }\end{array}$ \\
\hline $\begin{array}{l}\text { 4. Ex situ ES increase } \\
\text { as a CSR strategy }\end{array}$ & $\begin{array}{l}\text { Businesses that neither benefit from, } \\
\text { nor have an impact on service } \\
\text { provision, nor counteract the benefits } \\
\text { of service provision, but seek indirect } \\
\text { financial gains through a } \\
\text { CSR rationale. } \\
\text { (Moderate PES potential) }\end{array}$ & $\begin{array}{l}\text { Businesses could finance PES to gain } \\
\text { license to operate (LTO) at the local } \\
\text { level, and potentially improve public } \\
\text { image and generate positive media } \\
\text { attention at the national/global } \\
\text { level—which helps to build brand } \\
\text { capital and customer loyalty, in theory } \\
\text { leading to indirect ROI via } \\
\text { increased sales. }\end{array}$ & $\begin{array}{l}\text { Integrating ES into a business as part } \\
\text { of a CSR strategy rather than a } \\
\text { production strategy. Financing PES as } \\
\text { a third party so that other } \\
\text { stakeholders benefit from the ES. }\end{array}$ \\
\hline $\begin{array}{l}\text { 5. Reducing ES loss } \\
\text { in situ }\end{array}$ & $\begin{array}{l}\text { Businesses that benefit from } \\
\text { disrupting service provision at } \\
\text { operation sites (typically } \\
\text { extractive industries). } \\
\text { (Low PES potential) }\end{array}$ & $\begin{array}{l}\text { Businesses could be legally required } \\
\text { or morally motivated to invest in } \\
\text { reducing ES loss in situ by changing } \\
\text { operational practices at their } \\
\text { sites-but this is not PES per se. }\end{array}$ & $\begin{array}{l}\text { A business that uses ES (typically } \\
\text { provisioning services like timber) on } \\
\text { land under its jurisdiction applies } \\
\text { environmental practices to ensure } \\
\text { sustainable use. }\end{array}$ \\
\hline $\begin{array}{l}\text { 6. In situ ES } \\
\text { 'philanthropy' }\end{array}$ & $\begin{array}{l}\text { Businesses that neither benefit from, } \\
\text { nor have an impact on service } \\
\text { provision, nor counteract the benefits } \\
\text { of service provision elsewhere, but } \\
\text { wish to create leverage } \\
\text { with government. } \\
\text { (Unknown PES potential) }\end{array}$ & $\begin{array}{l}\text { Creating leverage by generating ES in } \\
\text { situ (i.e., at the site of operation) that } \\
\text { flow freely to society. }\end{array}$ & $\begin{array}{l}\text { In situ business practices that-either } \\
\text { deliberately, or as a by-product of } \\
\text { production-generate ES that flow to } \\
\text { other beneficiaries for free (i.e., } \\
\text { positive environmental externalities). }\end{array}$ \\
\hline
\end{tabular}

Business profiles with high PES potential involve those with ex situ production inputs, e.g., bottling plants requiring sustained and purified water. Thus, sustainability strategies and activities that seek to safeguard (Table $1, \# 1$ ) or optimise (Table 1,\#2) the provision and flows of such ecosystem services through long-term (rather than one-off) environmental management actions will be important. As noted, watershed PES typically involves strategic forest restoration upstream to improve water retention in the catchment area and maintain or enhance flows to downstream water users. The PES transaction involves downstream beneficiaries paying upstream providers to perform PES activities that deliver enhanced water quality and quantity such as reforestation and check dam construction [81,82,89].

Business profiles with moderate PES potential occur when the ecosystem services are 'used' for offsetting. A company may desire ecosystem services not as a production input, but to internalise negative environmental externalities such as carbon emissions. In this way, ecosystem services will still be considered in corporate production strategies, because carbon offsetting can (controversially) prevent the need to reduce production, and therefore 
help avoid fines associated with not meeting emissions targets (Table 1, \#3). The bilateral nature of PES promotes the purchase of carbon credits from specific partner-communities, rather than abstract carbon markets. This can value-add additional benefits; for example, such a scheme may also deliver co-benefits in the form of non-carbon ecosystem services that are important for local communities. In this way, a company may 'use' the ecosystem services not (only) to maintain or increase production, but for additional co-benefits akin to those achieved through corporate social responsibility (CSR) activities that can add value through their coverage in a sustainability report (Table $1, \# 4$ ).

Business profiles with low PES potential involve in situ production inputs (i.e., those taking place at the operation site). Businesses that rely on habitat conversion (e.g., palm oil production and cattle ranching) or extractive industries (e.g., mining) may be restricted in what they can achieve through PES, because in situ actions go against the off-site nature of PES [11] (Table 1, \#5). In such cases, biodiversity offsetting may offer a more rational approach [90]. Additionally, it is important to note that in implementing environmentally responsible practices at operation sites, a corporation may either deliberately or as a byproduct of production provide its own ecosystem services that flow to beneficiaries located elsewhere. One example comes from the Philippines, where the Energy Development Corporation (the world's second largest hydrothermal power company) provides numerous ecosystem services as a result of its production, such as improved soil structure, species diversity, and new agroforests, through its expansive reforestation activities on government land adjacent to its operation sites. Similar findings have been found with sugarcane companies in Malawi [37]. Of course, it is difficult to comprehend how a corporation could receive payments as an ecosystem service provider; indeed, the only plausible paying beneficiary would be government-particularly if a corporation provided ecosystem services that government deemed important for its people. Nevertheless, this 'ecosystem service philanthropy' may allow corporations to gain leverage in future negotiations with governments or stakeholders that receive the ecosystem services they are producing; for example, when renegotiating taxes or access rights to resources [72,91] (Table 1,\#6). While PES definitions do not explicitly state that corporations cannot be paid, further research into this potential financial incentive for corporations to practice corporate sustainability warrants further investigation.

\section{Best-Practices for Corporate-Financed PES: Lessons Learned}

This section synthesises the findings of empirical studies that have investigated corporate involvement in either prospective or operational PES schemes in Africa [37], Asia [4,18,92,93], Europe [16,35,56,61,94], Latin America [38,60,95], and North America $[24,96]$. In doing so, it provides a current textual account of lessons learned in moving from theory to practice. It also develops a framework that corporations interested in participating in PES and proponents seeking to develop corporate-financed PES schemes can heed moving forward.

This section is important because while corporations are increasingly sensitised to ecosystem services and natural capital through sustainability reporting frameworks and standards [78], their knowledge of PES as a means to maintain or enhance the ecosystem services upon which their business operations rely is often low and/or misinformed [4]. While Sections 3 and 4 go some way towards addressing this, corporations usually become aware of PES having been approached by a PES proponent from the public or civil sector [97], and it is critical that all parties understand exactly what a corporate-financed PES scheme 'should' or 'could' resemble-with eight key criteria synthesised from the literature, and with examples provided (Figure 3). While these prescribed criteria would represent an ideal corporate-financed PES scheme in theory (left side of Figure 3), it is ambitious to expect corporations to deliver on all of these. Indeed, evidence from the literature suggests that some modification will be necessary in order to get a corporate-financed PES scheme off the ground in practice (right side of Figure 3). 


\section{SO, IN THEORY..}

CRITERIA

BUT, IN PRACTICE..

Environmental management activities financed through PES schemes should be additional to current efforts financed by the corporation.

Example: In France, Vittel pay upland farmers an average of $€ 200 \mathrm{ha}^{-1}$ $\mathrm{yr}^{-1}$ to avoid using agrochemicals that could jeopardise the purity of their mineral water - but these chemicals would still be used were the PES scheme not in place [61].

Focus should be on specific ecosystem services that are important to the company's business model.

Example: In Italy, $20 \%$ of revenues from tourism operators in Natura 2000 sites is spent on protection of existing natural capital upon which those business rely [94]

\section{1}

Ensure that PES activities are additional ecosystem service
Pay for a specific type of improved or scaled. corporations.
Focus should be on ecosystem services that are generated offsite, from relevant and strategic locations.

Example: In the city of Southampton, UK, $60 \%$ of business owners involved in a proposed urban PES scheme were only willing to pay for street trees that were in the immediate vicinity of their premises, so that they could benefit directly from improved aesthetics and employee health [35].

\section{3}

Pay for ecosystem services from specific locations

Activities need not necessarily be completely new but could be

Example: In Thailand, corporations admitted that prior to participating in a PES schemes, they had already been financing the same activities (e.g., tree planting); however, the PES scheme did encourage them to increase in the frequency and/or quality [4].

If specific ecosystem services cannot be identified, low hanging fruit such as offsetting greenhouse gas emissions by paying for forest carbon credits, could offer a more generic option for most

Example: In Vietnam, the PFES scheme mandates companies to pay for a bundle of four different ecosystem services, some of which may be irrelevant to their business model [93].

The source of ecosystem services could not be precisely known or useable (for example, the hydrology of a watershed is difficult to map) so an approximate or adjacent location could be used.

Example: In the city of Sacramento, California, a construction company has financed the planting of 580 trees in private gardens, to offset carbon emissions from its work vehicles [96] - while strategic given the company operates in the city, these trees could have been planted anywhere for similar climate change mitigation impact [13].

Payment amounts should match what land managers are willing-toaccept, which will often be based on the opportunity costs they incur by participating in the scheme.
Example: In Nicaragua, a sugar company pays land managers US\$30 ha ${ }^{1} \mathrm{yr}^{-1}$ to protect and restore forests, with the amount based on the price that could be obtained by leasing the land to farmers for agriculture [38].

Since PES is a tool for sustainable production operations and risk management, payments should come from the main corporate budget - rather than e.g., their foundation.

Example: In Thailand, an agribusiness has separated their PES and CSR budgets, suggesting that PES has been institutionalised into the corporation's strategy and was now regarded as something different to CSR - giving the PES scheme an important degree of autonomy [4]
Initially, this could need to be balanced with the corporation's willingness-to-pay, since they may not be comfortable making (likely) large payments during the early years before they detect the benefits of the scheme.

Make financial or in-kind payments to land managers

Example: In Vietnam, costal ecosystem services were valued at VND $5.7 \mathrm{M} \mathrm{ha}^{-1} \mathrm{yr}^{-1}$ but aquaculture companies only offered VND 0.5 $\mathrm{M} \mathrm{ha}^{-1}$ $\mathrm{yr}^{-1}$ towards the scheme [92].

\section{5}

Allocate payments from the main operations budget

Initially, corporations could only be comfortable budgeting for PES from their foundation's budget, or the CSR budget - again, until verified benefits of the scheme can be seen.

Example: In Malawi, tobacco and sugarcane companies were unwilling to participate in PES schemes if extra financial obligations are demanded without evidence of the benefits, and would only be willing to implement PES schemes as part of their CSR activities and using CSR funds [37].

Payments should ideally be conditional on the verified performance of the PES scheme - i.e., made once benefits have been detected.

Example: In the USA, two watershed PES schemes specified that they conduct counterfactual evaluations with control watersheds to verify that hydrological improvements are due to the schemes [54].

Favour performance-based conditionality
PES is a transaction in which payments should be made in exchange for ecosystem service delivery that provides a return on that outlay (e.g., through production efficiencies, avoiding fines).

Example: In California, agribusinesses are involved in PES to build supply chain resilience through carbon insetting - reducing $\mathrm{CO}_{2}$ emissions in their supply chains by paying supplier farmers to change their land management practices, helping them meet emissions reduction targets and avoid fines [24] are incentivised to continue performing the necessary environmenta management activities.

Example: In Costa Rica, the PSA program uses 5-year contracts between hydropower companies and upstream landowners, with the option to renew usually taken up by the former, suggesting they consider the benefits exceed the cost [60].
Initially, corporations could be agreeable to 'output-based conditionality' based on the completion of activities (e.g., number of trees planted) whist awaiting verifiable benefits.

Example: In Thailand, conditionality was determined by monitoring the completion of activities, rather than companies measuring production performance [4].

Additionally, or alternatively, potential co-benefits could be achieved similar to those gained through CSR (e.g., reputation enhancement). These may be sufficient to encourage involvement if verified benefits are absent or delayed.

Example: In Germany, corporate interviewees could not envision how PES would contribute directly to financial business success [16].
Aspire to see a return on investment (ROI) 
meaning that the ecosystem service maintenance or enhancement is additional to what would have been occurred without the PES scheme [61]. In practice, the activities themselves need not necessarily be completely new, but should be expanded or improved; for example, by using more effective practices, covering a larger area, or encompassing a longer timeframe [4].

\section{Criterion 2: Corporations should pay for a specific type of ecosystem service}

In theory, corporations should understand that payments should be made for specific ecosystem services, provision of which is important to their business model (as discussed in Section 3). The ecosystem service should be a logical and strategic choice and will vary depending on the type of business profile. For example, an ecotourism operator might be expected to participate in a biodiversity PES scheme, paying land managers to enhance the quality and size of relevant habitats, in order to increase the abundance and/or diversity of species that tourists hope to see (leading to more tourists and revenues) [94]. In practice, there may be situations where specific ecosystem services cannot be identified, in which case 'low hanging fruit' such as offsetting greenhouse gas emissions by paying for forest carbon credits could offer a more generic option for corporations that are keen to get involved in PES. Ecosystem services can also be bundled together with others, to create a diversified portfolio of services; and, while corporations may only benefit slightly from each one, the cumulative benefit may be sufficient to encourage their participation. Due to an absence of clearly defined ecosystem services and a shortfall of in-country hydrology and physical science skills, corporations enrolled in Vietnam's PFES program, for instance, have to pay for a generic bundle of services including watershed protection for hydropower, landscape beauty for tourism, provision of spawning grounds for aquaculture, and forest carbon sequestration for emissions reduction $[59,93]$.

Criterion 3: Corporations should pay for ecosystem services from specific locations

In theory, corporations should understand that PES aims to deliver internal performance outcomes (i.e., production efficiency, risk management, and direct ROI) through the implementation of external activities performed ex situ, offsite [4]. While many CSR activities are conducted offsite, many corporations will have internal protocols stipulating a maximum distance offsite beyond which corporate-financed activities cannot be practiced [18]. Since the most strategic locations for implementing environmental management activities to maximise ecosystem service maintenance or enhancement may be located far beyond these zones (e.g., in a distant catchment area), in practice, these protocols may need to be relaxed to enable corporate participation in PES [18]. Additionally, PES sites should be as locally relevant as possible so as to increase buy-in among ecosystem service providers, linking to the aforementioned added benefits of LTO. An example would be choosing to purchase forest carbon credits from a proximal reforestation scheme, or at least from one within the same country, rather than a forest on the opposite side of the world. Climate change mitigation may be a global service, but by paying for this from local forests, these value-added corporate sustainability benefits can be achieved (see Section 3).

Criterion 4: Corporations should make financial or in-kind payments to land managers

In theory, corporations should understand that PES requires them to make payments to land managers. The payment amount should ideally be one that these land managers are willing to accept, which will often be based on the scientifically determined economic value of the ecosystem services and/or the opportunity costs they incur by participating in the scheme (i.e., changing their land management practices in a way that generates less revenue). For example, in Nicaragua, a sugar company pays land managers US\$30 ha ${ }^{-1}$ $\mathrm{yr}^{-1}$ to protect and restore forests, with the amount based on the price that could have been obtained by leasing the land to farmers for agriculture [38]. In practice, however, this may need to be balanced with the corporation's willingness-to-pay, since it may not be comfortable making (likely) large payments during the early stages before it can detect any direct benefits of the scheme to their operations and finances. For example, in Vietnam, coastal ecosystem services were valued at VND 5.7 $\mathrm{M} \mathrm{ha}^{-1} \mathrm{yr}^{-1}$ but aquaculture companies only offered payments of VND $0.5 \mathrm{M} \mathrm{ha}^{-1} \mathrm{yr}^{-1}$ to coastal land managers [92]. Hence, 
tolerating buyer willingness-to-pay may be the only way a PES scheme can initially get off the ground.

Criterion 5: Corporations should allocate payments from the main operations budget

In theory, corporations should understand that since PES is a tool to improve the sustainability of production operations through ensuring the long-term delivery of key production inputs (i.e., risk management), payments should come from the main corporate budget-rather than, for example, their foundation or the CSR department budget [4]. In practice, though, corporations tend to utilise the latter sources, again due to initial scepticism, or simply a lack of evidence that they will see true operational improvements and financial returns on the payments $[16,37,95]$. It should be noted that there may be relevant external institutions that corporations can tap into to achieve this. For example, in the Philippines, under the Electric Power Industry Reform Act (EPIRA), 25\% of one centavo per $\mathrm{kWh}\left(\mathrm{PhP} 0.0025 \mathrm{kWh}^{-1}\right.$ ) of energy sales accrues to a fund that is used to support oneoff environment and development projects in communities adjacent to energy production sites, which are typically hydropower operations in watersheds. EPIRA does not mandate energy producers to participate in PES, but some corporations have decided to reallocate these funds as PES payments [50]; this eased adoption because the corporation did not have to find additional funds (i.e., neither through their operations nor CSR budgets). Similar practices occur in Costa Rica's PSA program, where water utilities companies can deduct PES payments from their government-mandated water tariffs [60]. Identifying such institutional leverage points could increase corporate action on ecosystem services and biodiversity conservation [1].

\section{Criterion 6: Corporations should favour performance-based conditionality}

In theory, corporations should understand that their payments should be conditional on the performance of the PES scheme. This is termed 'performance-based' conditionality and means that actual financial returns or operational improvements are verified prior to payment. PES theorists have long suggested that this should be desired over 'output-based conditionality', in which payments are made merely upon verification that the activities (supposed to maintain or enhance ecosystem service provision) have been completed. More recently, however, Wunder et al. [22] seemingly relaxed the requirement that payments are conditional on the verified delivery of services. This is probably prudent in the face of mounting evidence suggesting that the private sector is unlikely to be interested in funding expensive scientific ecosystem service assessments and may be happy to forgo high data accuracy in favour of simpler, lower-cost, and more rapid methods [17,18]. There are also cases of private sector beneficiaries ignoring scientifically determined values in favor of their own willingness-to-pay, as noted in the Vietnam case above [92]—and similar was found for a proposed urban PES scheme in the UK [35]. Hence, in practice, accepting output-based conditionality based on the completion of management practices may be necessary.

\section{Criterion 7: Corporations should aspire to see a return on investment}

In theory, corporations should understand that they should at least hope to see a financial return on their payments, through the aforementioned operational, production, and risk mitigation improvements. PES should be viewed as a transaction in which payments are made in exchange for ecosystem service delivery that provides a return on that outlay (e.g., through production efficiencies or avoiding fines). For example, Biggs et al. [24] note that agribusinesses in the USA use PES to build supply chain resilience through carbon insetting (reducing $\mathrm{CO}_{2}$ emissions in their supply chains by paying supplier farmers to change their land management practices), which helps them to meet their emissions reduction targets and avoid fines [24]. As noted in Sections 3 and 4 however, in practice some corporations may be content with the co-benefits of a prospective PES scheme, which may be similar to outcomes sought from traditional CSR activities (e.g., positive media coverage and reputation enhancement). These co-benefits can encourage corporations to remain involved in cases where financial returns are not forthcoming, or difficult to verify with certainty [16]. 


\section{Criterion 8: Corporations should make these payments repeatedly}

In theory, corporations should understand that PES relies on continuous financing to land managers so that they are incentivised to continue performing the necessary environmental management activities that help maintain or enhance ecosystem service provision. PES is not a one-off payment akin to many CSR projects; PES schemes typically last for $>10$ years and payments are usually made annually. Contrary to the views of some corporate executives, PES schemes cannot be 'handed over' akin to the way a corporate might gradually reduce support such that a community takes over their CSR project [18]. Generally, once payments stop, the PES scheme would terminate-although there are limited cases of land managers continuing the PES activities once payments cease, because they have been educated the importance of natural resource management [98]. A favourable example of this comes from Costa Rica where the PSA program uses five-year contracts between hydropower companies and upstream landowners, with the option to renew usually taken up by the former, suggesting they consider the benefits to exceed the cost [60]. Nevertheless, in practice, corporations may be reluctant to sign long-term contracts; indeed, oftentimes, approval for participation may need to be sought from the board every year-making the eventual verification of operational and financial benefits crucial [18].

\section{Balancing theoretical criteria with practical realities}

The narrative above signals that certainly in the initial stages of corporate-financed PES scheme design and implementation, PES theory must be balanced with practical realities. While clarifying the theory (the eight criteria) to corporations is of paramount importance to ensure they fully grasp the concept of PES, supplementing this with options to loosen these theoretical underpinnings, at least initially, will likely be necessary to get corporatefinanced PES schemes off the ground. This may require practitioners to lower expectations, in a bid to 'start small' with a pilot scheme. For instance, the payment amount may be less important than the action of establishing collaboration between providers and beneficiaries, and encouraging the action of signing memoranda of understandings (MOUs) and PES contracts. While it is important that payments meet sellers' willingness-to-accept (since very low payments could be considered 'meaningless', which could lead to low participation or low compliance with contract terms [86]), a voluntary rolling contract could present low risk for both parties, with providers performing activities in a smaller area, and corporations making initial payments based on output-based conditionality. These payments could then be increased and the scheme scaled up should the corporation be satisfied with the benefits it receives. These initial payments could come from the CSR or foundation arm of the corporation-funds which fall under lower scrutiny that those coming from the main operations arm [18]. This situation may also require intermediaries/facilitators to cover costs and efforts on initial ecosystem service assessments, and potentially some of the initial payments to providers to jump-start the scheme. This was the case for a PES scheme involving a sugarcane company in Nicaragua, where the Global Environment Facility instigated the project [38].

\section{Conclusions}

Voluntary corporate-financed PES schemes remain small in number and size, but have significant potential to increase $[4,16]$. For this potential to be realised, greater effort is required to connect PES and business scholarship, and to scrutinise how corporatefinanced PES occurs in practice. This article has demonstrated how corporations fit into the economic theory that underpins PES, by financing schemes though an array of mandated taxes, philanthropic initiatives, or investments in sustainable production. It is shown that corporate-financed PES schemes are diverse, and often hybridise Coasean and Pigouvian economic theories. The article has further portrayed PES as an integrated corporate sustainability strategy that can contribute jointly to the economic, environmental, and social tenets of the triple-bottom line. Subsequently, it has elucidated different PES options for corporations based on their business profile and requirements, with PES schemes that 
maintain or enhance ecosystem service delivery or reduce or offset ecosystem service losses being of highest potential. Finally, key lessons learned when moving from theory to practice have been synthesised from the latest empirical research on corporate-financed PES. It is noted that while certain criteria can be prescribed that would represent an ideal corporatefinanced PES scheme in theory, empirical evidence suggests that some modification will be necessary in order to implement such a scheme in practice. For example, implementing a corporate-financed PES scheme may require relaxing inhibitive corporate protocols [18], utilising external enabling institutions [50], and ensuring that the business rationales for PES are fully understood across multiple departments and managerial levels of a firm [4].

In terms of future research, while hypothetical studies are valuable in designing and gauging interest in corporate-financed PES schemes, scholars should increasingly focus on exploring the development and workings of operational corporate-financed schemesscrutinising corporate motives, understandings, and actions on PES. As these schemes begin to demonstrate a track record, there may be opportunities to quantify the extent to which maintained or enhanced ecosystem service provision can actually affect corporate performance-this is the holy grail of corporate-financed PES research, but it remains very challenging to achieve in practice given the myriad factors that can affect ecosystem service delivery, production inputs and outputs, and corporate financial performance.

Researchers could also use a broader sample of corporations in their analyses, in terms of sizes and sectors. While there has been coverage of large multi-national corporations [24] and large national corporations [4] that engage in operational PES schemes, there has been limited attention towards small- to medium-sized enterprises (SMEs) and micro businesses [35]. It would also be interesting to study the complementarity between corporate participation and institutional and governance mechanisms that can help mitigate upfront financial risks and technical challenges during design, piloting, and implementation. More economic viability studies are also required, which would involve comparing the amounts corporations are willing to pay for ecosystem services to the opportunity costs that providers would incur [99]. These payment amounts could also be compared to the minimum and aspirational financial and non-financial outcomes that corporations expect to achieve through engaging in a PES scheme. Finally, critical scholars also have an opportunity to scrutinise the fairness of bargaining processes when payment amounts are negotiated, as recent studies have indicated [56]. Ultimately, such research would benefit from increased knowledge coproduction and collaboration between scholars and practitioners of business, economics, environmental studies, and social sciences.

Funding: This research received no external funding.

Conflicts of Interest: The author declares no conflict of interest.

\section{References}

1. Krause, M.S.; Droste, N.; Matzdorf, B. What makes businesses commit to nature conservation? Bus. Strategy Environ. 2020, 30, 741-755. [CrossRef]

2. Smith, T.; Beagley, L.; Bull, J.; Milner-Gulland, E.J.; Smith, M.; Vorhies, F.; Addison, P.F.E. Biodiversity means business: Reframing global biodiversity goals for the private sector. Conserv. Lett. 2019, 13, e12690. [CrossRef]

3. Geissdoerfer, M.; Savaget, P.; Bocken, N.M.P.; Hultink, E.J. The Circular Economy-A new sustainability paradigm? J. Clean. Prod. 2017, 143, 757-768. [CrossRef]

4. Thompson, B.S. Payments for ecosystem services and corporate social responsibility: Perspectives on sustainable production, stakeholder relations, and philanthropy in Thailand. Bus. Strategy Environ. 2019, 28, 497-511. [CrossRef]

5. Smith, T.; Paavola, J.; Holmes, G. Corporate reporting and conservation realities: Understanding differences in what businesses say and do regarding biodiversity. Environ. Policy Gov. 2018, 29, 3-13. [CrossRef]

6. Svensson, G.; Ferro, C.; Høgevold, N.; Padin, C.; Carlos Sosa Varela, J.; Sarstedt, M. Framing the triple bottom line approach: Direct and mediation effects between economic, social and environmental elements. J. Clean. Prod. 2018, 197, 972-991. [CrossRef]

7. Seymour, F. Seeing the forests as well as the (trillion) trees in corporate climate strategies. One Earth 2020, 2, 390-393. [CrossRef]

8. D'Amato, D.; Wan, M.; Li, N.; Rekola, M.; Toppinen, A. Managerial views of corporate impacts and dependencies on ecosystem services: A case of international and domestic forestry companies in China. J. Bus. Ethics 2016, 150, 1011-1028. [CrossRef]

9. van den Belt, M.; Blake, D. Investing in Natural Capital and Getting Returns: An Ecosystem Service Approach. Bus. Strategy Environ. 2015, 24, 667-677. [CrossRef] 
10. Watson, S.; Newton, A. Dependency of businesses on flows of ecosystem services: A case study from the county of Dorset, UK. Sustainability 2018, 10, 1368. [CrossRef]

11. Wunder, S. Revisiting the concept of payments for environmental services. Ecol. Econ. 2015, 117, 234-243. [CrossRef]

12. Leimona, B.; van Noordwijk, M.; de Groot, R.; Leemans, R. Fairly efficient, efficiently fair: Lessons from designing and testing payment schemes for ecosystem services in Asia. Ecosyst. Serv. 2015, 12, 16-28. [CrossRef]

13. Richards, D.R.; Thompson, B.S. Urban ecosystems: A new frontier for payments for ecosystem services. People Nat. 2019, 1, 249-261. [CrossRef]

14. Jayachandran, S.; de Laat, J.; Lambin, E.F.; Stanton, C.Y.; Audy, R.; Thomas, N.E. Cash for carbon: A randomized trial of payments for ecosystem services to reduce deforestation. Science 2017, 357, 267-273. [CrossRef]

15. Bladon, A.J.; Short, K.M.; Mohammed, E.Y.; Milner-Gulland, E.J. Payments for ecosystem services in developing world fisheries. Fish Fish. 2016, 17, 839-859. [CrossRef]

16. Krause, M.S.; Matzdorf, B. The intention of companies to invest in biodiversity and ecosystem services credits through an online-marketplace. Ecosyst. Serv. 2019, 40, e101026. [CrossRef]

17. Reed, M.S.; Allen, K.; Attlee, A.; Dougill, A.J.; Evans, K.L.; Kenter, J.O.; Hoy, J.; McNab, D.; Stead, S.M.; Twyman, C.; et al. A place-based approach to payments for ecosystem services. Glob. Environ. Chang. 2017, 43, 92-106. [CrossRef]

18. Thompson, B.S. Institutional challenges for corporate participation in payments for ecosystem services (PES): Insights from Southeast Asia. Sustain. Sci. 2018, 13, 919-935. [CrossRef]

19. Goldman-Benner, R.L.; Benitez, S.; Boucher, T.; Calvache, A.; Daily, G.; Kareiva, P.; Kroeger, T.; Ramos, A. Water funds and payments for ecosystem services: Practice learns from theory and theory can learn from practice. Oryx 2012, 46, 55-63. [CrossRef]

20. Jack, B.K.; Kousky, C.; Sims, K.R. Designing payments for ecosystem services: Lessons from previous experience with incentivebased mechanisms. Proc. Natl. Acad. Sci. USA 2008, 105, 9465-9470. [CrossRef]

21. McElwee, P.; Huber, B.; Nguyễn, T.H.V. Hybrid outcomes of payments for ecosystem services policies in Vietnam: Between theory and practice. Dev. Chang. 2020, 51, 253-280. [CrossRef]

22. Wunder, S.; Brouwer, R.; Engel, S.; Ezzine-de-Blas, D.; Muradian, R.; Pascual, U.; Pinto, R. From principles to practice in paying for nature's services. Nat. Sustain. 2018, 1, 145-150. [CrossRef]

23. Muradian, R.; Corbera, E.; Pascual, U.; Kosoy, N.; May, P.H. Reconciling theory and practice: An alternative conceptual framework for understanding payments for environmental services. Ecol. Econ. 2010, 69, 1202-1208. [CrossRef]

24. Buckley Biggs, N.; Hafner, J.; Mashiri, F.; Huntsinger, L.; Lambin, E. Payments for ecosystem services within the hybrid governance model: Evaluating policy alignment and complementarity on California rangelands. Ecol. Soc. 2021, 26, e19. [CrossRef]

25. Engel, S.; Pagiola, S.; Wunder, S. Designing payments for environmental services in theory and practice: An overview of the issues. Ecol. Econ. 2008, 65, 663-674. [CrossRef]

26. Sattler, C.; Trampnau, S.; Schomers, S.; Meyer, C.; Matzdorf, B. Multi-classification of payments for ecosystem services: How do classification characteristics relate to overall PES success? Ecosyst. Serv. 2013, 6, 31-45. [CrossRef]

27. Sorice, M.G.; Donlan, C.J.; Boyle, K.J.; Xu, W.; Gelcich, S. Scaling participation in payments for ecosystem services programs. PLoS ONE 2018, 13, e0192211. [CrossRef]

28. Bennett, D.E.; Gosnell, H.; Lurie, S.; Duncan, S. Utility engagement with payments for watershed services in the United States. Ecosyst. Serv. 2014, 8, 56-64. [CrossRef]

29. Hejnowicz, A.P.; Raffaelli, D.G.; Rudd, M.A.; White, P.C.L. Evaluating the outcomes of payments for ecosystem services programmes using a capital asset framework. Ecosyst. Serv. 2014, 9, 83-97. [CrossRef]

30. Brouwer, R.O.Y.; Tesfaye, A.; Pauw, P. Meta-analysis of institutional-economic factors explaining the environmental performance of payments for watershed services. Environ. Conserv. 2011, 38, 380-392. [CrossRef]

31. Ola, O.; Menapace, L.; Benjamin, E.; Lang, H. Determinants of the environmental conservation and poverty alleviation objectives of Payments for Ecosystem Services (PES) programs. Ecosyst. Serv. 2019, 35, 52-66. [CrossRef]

32. Salzman, J.; Bennett, G.; Carroll, N.; Goldstein, A.; Jenkins, M. The global status and trends of Payments for Ecosystem Services. Nat. Sustain. 2018, 1, 136-144. [CrossRef]

33. Chaplin-Kramer, R.; Jonell, M.; Guerry, A.; Lambin, E.F.; Morgan, A.J.; Pennington, D.; Smith, N.; Franch, J.A.; Polasky, S. Ecosystem service information to benefit sustainability standards for commodity supply chains. Ann. N. Y. Acad. Sci. 2015, 1355, 77-97. [CrossRef]

34. Houdet, J.; Trommetter, M.; Weber, J. Understanding changes in business strategies regarding biodiversity and ecosystem services. Ecol. Econ. 2012, 73, 37-46. [CrossRef]

35. Davies, H.J.; Doick, K.J.; Hudson, M.D.; Schaafsma, M.; Schreckenberg, K.; Valatin, G. Business attitudes towards funding ecosystem services provided by urban forests. Ecosyst. Serv. 2018, 32, 159-169. [CrossRef]

36. Thompson, B.S.; Friess, D.A. Stakeholder preferences for payments for ecosystem services (PES) versus other environmental management approaches for mangrove forests. J. Environ. Manag. 2019, 233, 636-648. [CrossRef] [PubMed]

37. Chinangwa, L.; Gasparatos, A.; Saito, O. Forest conservation and the private sector: Stakeholder perceptions towards payment for ecosystem service schemes in the tobacco and sugarcane sectors in Malawi. Sustain. Sci. 2017, 12, 727-746. [CrossRef]

38. Aguilar-Støen, M. Exploring participation in new forms of environmental governance: A case study of payments for environmental services in Nicaragua. Environ. Dev. Sustain. 2014, 17, 941-958. [CrossRef]

39. Vatn, A. An institutional analysis of payments for environmental services. Ecol. Econ. 2010, 69, 1245-1252. [CrossRef] 
40. Ezzine-de-Blas, D.; Wunder, S.; Ruiz-Perez, M.; Moreno-Sanchez Rdel, P. Global patterns in the implementation of payments for environmental services. PLOS ONE 2016, 11, e0149847. [CrossRef]

41. Sattler, C.; Matzdorf, B. PES in a nutshell: From definitions and origins to PES in practice-Approaches, design process and innovative aspects. Ecosyst. Serv. 2013, 6, 2-11. [CrossRef]

42. Coase, R.H. The Problem of Social Cost. In Classic Papers in Natural Resource Economics; Gopalakrishnan, C., Ed.; Palgrave Macmillan: London, UK, 2000; pp. 87-137.

43. Cheung, S.N.S. Transaction costs, risk aversion, and the choice of contractual arrangements. J. Law Econ. 1969, $12,23-42$.

44. Hausknost, D.; Grima, N.; Singh, S.J. The political dimensions of Payments for Ecosystem Services (PES): Cascade or stairway? Ecol. Econ. 2017, 131, 109-118. [CrossRef]

45. Schomers, S.; Matzdorf, B. Payments for ecosystem services: A review and comparison of developing and industrialized countries. Ecosyst. Serv. 2013, 6, 16-30. [CrossRef]

46. Pigou, A.C. The Economics of Welfare; Macmillan: London, UK, 1920.

47. Diswandi, D. A hybrid Coasean and Pigouvian approach to Payment for Ecosystem Services Program in West Lombok: Does it contribute to poverty alleviation? Ecosyst. Serv. 2017, 23, 138-145. [CrossRef]

48. Vatn, A. Environmental governance-From public to private? Ecol. Econ. 2018, 148, 170-177. [CrossRef]

49. Vatn, A. Markets in environmental governance-From theory to practice. Ecol. Econ. 2014, 105, 97-105. [CrossRef]

50. Thompson, B.S.; Harris, J.L. Changing environment and development institutions to enable payments for ecosystem services: The role of institutional work. Glob. Environ. Chang. 2021, 67, e102227. [CrossRef]

51. Markova-Nenova, N.; Wätzold, F. PES for the poor? Preferences of potential buyers of forest ecosystem services for including distributive goals in the design of payments for conserving the dry spiny forest in Madagascar. For. Policy Econ. 2017, 80, 71-79. [CrossRef]

52. Jones, K.W.; Holland, M.B.; Naughton-Treves, L.; Morales, M.; Suarez, L.; Keenan, K. Forest conservation incentives and deforestation in the Ecuadorian Amazon. Environ. Conserv. 2016, 44, 56-65. [CrossRef]

53. Joslin, A.J.; Jepson, W.E. Territory and authority of water fund payments for ecosystem services in Ecuador's Andes. Geoforum 2018, 91, 10-20. [CrossRef]

54. Brownson, K.; Anderson, E.P.; Ferreira, S.; Wenger, S.; Fowler, L.; German, L. Governance of Payments for Ecosystem Ecosystem services influences social and environmental outcomes in Costa Rica. Ecol. Econ. 2020, 174, e106659. [CrossRef]

55. Muradian, R.; Rival, L. Between markets and hierarchies: The challenge of governing ecosystem services. Ecosyst. Serv. 2012, 1, 93-100. [CrossRef]

56. Bingham, L.R. Vittel as a model case in PES discourse: Review and critical perspective. Ecosyst. Serv. 2021, 48, e101248. [CrossRef]

57. Wynne-Jones, S. Connecting payments for ecosystem services and agri-environment regulation: An analysis of the Welsh Glastir Scheme. J. Rural Stud. 2013, 31,77-86. [CrossRef]

58. McElwee, P.D. Payments for environmental services as neoliberal market-based forest conservation in Vietnam: Panacea or problem? Geoforum 2012, 43, 412-426. [CrossRef]

59. Tran, T.T.H.; Zeller, M.; Suhardiman, D. Payments for ecosystem services in Hoa Binh province, Vietnam: An institutional analysis. Ecosyst. Serv. 2016, 22, 83-93. [CrossRef]

60. Blackman, A.; Woodward, R.T. User financing in a national payments for environmental services program: Costa Rican hydropower. Ecol. Econ. 2010, 69, 1626-1638. [CrossRef]

61. Perrot-Maître, D. The Vittel Case: A public-private partnership in the mineral water industry. In Case studies on Remuneration of Positive Externalities (RPE)/Payments for Environmental Services (PES), Proceedings of the Multi-Stakeholder Dialogue 12-13 September 2013; FAO: Rome, Italy, 2014.

62. Bremer, L.L.; Farley, K.A.; Lopez-Carr, D.; Romero, J. Conservation and livelihood outcomes of payment for ecosystem services in the Ecuadorian Andes: What is the potential for 'win-win'? Ecosyst. Serv. 2014, 8, 148-165. [CrossRef]

63. Antolín-López, R.; Delgado-Ceballos, J.; Montiel, I. Deconstructing corporate sustainability: A comparison of different stakeholder metrics. J. Clean. Prod. 2016, 136, 5-17. [CrossRef]

64. Elkington, J. Enter the Triple Bottom Line. In The Triple Bottom Line; Routledge: Abingdon-on-Thames, UK, 1997.

65. Hörisch, J.; Wulfsberg, I.; Schaltegger, S. The influence of feedback and awareness of consequences on the development of corporate sustainability action over time. Bus. Strategy Environ. 2019, 29, 638-650. [CrossRef]

66. Kitsios, F.; Kamariotou, M.; Talias, M.A. Corporate sustainability strategies and decision support methods: A bibliometric analysis. Sustainability 2020, 12, 521. [CrossRef]

67. Gupta, S.; Chen, H.; Hazen, B.T.; Kaur, S.; Santibañez Gonzalez, E.D.R. Circular economy and big data analytics: A stakeholder perspective. Technol. Forecast. Soc. Chang. 2019, 144, 466-474.

68. Birkel, H.; Müller, J.M. Potentials of industry 4.0 for supply chain management within the triple bottom line of sustainability-A systematic literature review. J. Clean. Prod. 2021, 289, e125612. [CrossRef]

69. Liu, X.; Yang, J.; Qu, S.; Wang, L.; Shishime, T.; Bao, C. Sustainable production: Practices and determinant factors of green supply chain management of Chinese companies. Bus. Strategy Environ. 2012, 21, 1-16. [CrossRef]

70. Tiwari, K.; Khan, M.S. Sustainability accounting and reporting in the industry 4.0. J. Clean. Prod. 2020, 258, e120783. [CrossRef]

71. O'Shea, T.; Golden, J.S.; Olander, L. Sustainability and Earth Resources: Life Cycle Assessment Modeling. Bus. Strategy Environ. 2013, 22, 429-441. [CrossRef] 
72. D'Amato, D.; Li, N.; Rekola, M.; Toppinen, A.; Lu, F.F. Linking forest ecosystem services to corporate sustainability disclosure: A conceptual analysis. Ecosyst. Serv. 2015, 14, 170-178. [CrossRef]

73. Barton, D.N.; Benavides, K.; Chacon-Cascante, A.; Le Coq, J.-F.; Quiros, M.M.; Porras, I.; Primmer, E.; Ring, I. Payments for Ecosystem Services as a Policy Mix: Demonstrating the institutional analysis and development framework on conservation policy instruments. Environ. Policy Gov. 2017, 27, 404-421. [CrossRef]

74. Dyllick, T.; Hockerts, K. Beyond the business case for corporate sustainability. Bus. Strategy Environ. 2002, 11, 130-141. [CrossRef]

75. Polasky, S.; Tallis, H.; Reyers, B. Setting the bar: Standards for ecosystem services. Proc. Natl. Acad. Sci. USA 2015, 112, 7356-7361. [CrossRef] [PubMed]

76. Porter, M.E.; Kramer, M.R. Strategy and society: The link between competitive advantage and corporate social responsibility. Harv. Bus. Rev. 2011, 84, 78-92.

77. Bhattacharya, T.R.; Managi, S. Contributions of the private sector to global biodiversity protection: Case study of the Fortune 500 companies. Int. J. Biodivers. Sci. Ecosyst. Serv. Manag. 2012, 9, 65-86. [CrossRef]

78. Winn, M.I.; Pogutz, S. Business, Ecosystems, and Biodiversity. Organ. Environ. 2013, 26, 203-229.

79. Thampapillai, D.J.; Sinden, J.A. Environmental Economics: Concepts, Methods and Policies; Oxford University Press: Melbourne, Australia, 2013.

80. Bauchet, J.; Asquith, N.; Ma, Z.; Radel, C.; Godoy, R.; Zanotti, L.; Steele, D.; Gramig, B.M.; Chong, A.E. The practice of Payments for Ecosystem Services (PES) in the tropical Andes: Evidence from program administrators. Ecosyst. Serv. 2020, 45, e101175. [CrossRef]

81. Asquith, N.M.; Vargas, M.T.; Wunder, S. Selling two environmental services: In-kind payments for bird habitat and watershed protection in Los Negros, Bolivia. Ecol. Econ. 2008, 65, 675-684. [CrossRef]

82. Turpie, J.K.; Marais, C.; Blignaut, J.N. The working for water programme: Evolution of a payments for ecosystem services mechanism that addresses both poverty and ecosystem service delivery in South Africa. Ecol. Econ. 2008, 65, 788-798. [CrossRef]

83. Gross-Camp, N.D.; Martin, A.; McGuire, S.; Kebede, B.; Munyarukaza, J. Payments for ecosystem services in an African protected area: Exploring issues of legitimacy, fairness, equity and effectiveness. Oryx 2012, 46, 24-33. [CrossRef]

84. Rangan, K.; Chase, L.A.; Karim, S. Why Every Company Needs a CSR Strategy and How to Build it; Harvard Business School: Boston, MA, USA, 2021.

85. Kosoy, N.; Martinez-Tuna, M.; Muradian, R.; Martinez-Alier, J. Payments for environmental services in watersheds: Insights from a comparative study of three cases in Central America. Ecol. Econ. 2007, 61, 446-455. [CrossRef]

86. Thompson, B.S.; Primavera, J.H.; Friess, D.A. Governance and implementation challenges for mangrove forest Payments for Ecosystem Services (PES): Empirical evidence from the Philippines. Ecosyst. Serv. 2017, 23, 146-155. [CrossRef]

87. Shou, Y.; Shao, J.; Lai, K.-h.; Kang, M.; Park, Y. The impact of sustainability and operations orientations on sustainable supply management and the triple bottom line. J. Clean. Prod. 2019, 240, e118280. [CrossRef]

88. Montiel, I.; Delgado-Ceballos, J. Defining and Measuring Corporate Sustainability. Organ. Environ. 2014, 27, 113-139. [CrossRef]

89. Zheng, H.; Robinson, B.E.; Liang, Y.C.; Polasky, S.; Ma, D.C.; Wang, F.C.; Ruckelshaus, M.; Ouyang, Z.Y.; Daily, G.C. Benefits, costs, and livelihood implications of a regional payment for ecosystem service program. Proc. Natl. Acad. Sci. USA 2013, 110, 16681-16686. [CrossRef] [PubMed]

90. Bull, J.W.; Suttle, K.B.; Gordon, A.; Singh, N.J.; Milner-Gulland, E.J. Biodiversity offsets in theory and practice. Oryx 2013, 47, 369-380. [CrossRef]

91. Dauvergne, P.; Lister, J. Big brand sustainability: Governance prospects and environmental limits. Glob. Environ. Chang. 2012, 22, 36-45. [CrossRef]

92. Wylie, L.; Sutton-Grier, A.E.; Moore, A. Keys to successful blue carbon projects: Lessons learned from global case studies. Mar. Policy 2016, 65, 76-84. [CrossRef]

93. Pham, T.T.; Loft, L.; Bennett, K.; Phuong, V.T.; Dung, L.N.; Brunner, J. Monitoring and evaluation of Payment for Forest Environmental Services in Vietnam: From myth to reality. Ecosyst. Serv. 2015, 16, 220-229. [CrossRef]

94. Schirpke, U.; Scolozzi, R.; Da Re, R.; Masiero, M.; Pellegrino, D.; Marino, D. Enhancing outdoor recreation and biodiversity through payments for ecosystem services: Emerging potentials from selected Natura 2000 sites in Italy. Environ. Dev. Sustain. 2018, 22, 2045-2067. [CrossRef]

95. de Lima, L.S.; Krueger, T.; García-Marquez, J. Uncertainties in demonstrating environmental benefits of payments for ecosystem services. Ecosyst. Serv. 2017, 27, 139-149. [CrossRef]

96. Schadler, E.; Danks, C.; Carbon Offsetting through Tree Planting. The Sacramento Tree Foundation and Harbison-MahonyHiggins Builders Inc. Available online: http://www.uvm.edu/ \{\}cfcm/casestudies/Sacramento\%20Tree\%20Foundation.pdf (accessed on 10 July 2021).

97. Huber-Stearns, H.R.; Goldstein, J.H.; Duke, E.A. Intermediary roles and payments for ecosystem services: A typology and program feasibility application in Panama. Ecosyst. Serv. 2013, 6, 104-116. [CrossRef]

98. Andersson, K.P.; Cook, N.J.; Grillos, T.; Lopez, M.C.; Salk, C.F.; Wright, G.D.; Mwangi, E. Experimental evidence on payments for forest commons conservation. Nat. Sustain. 2018, 1, 128-135. [CrossRef]

99. Thompson, B.S.; Clubbe, C.P.; Primavera, J.H.; Curnick, D.; Koldewey, H.J. Locally assessing the economic viability of blue carbon: A case study from Panay Island, the Philippines. Ecosyst. Serv. 2014, 8, 128-140. [CrossRef] 